\title{
A Scenario of the Formative E-assessment Based on the ARCS Model: What Is the Impact on Student Motivation in Educational Context?
}

\author{
https://doi.org/10.3991/ijet.v16i24.24121 \\ Halima Lajane ${ }^{(\varpi)}$, Mounir Arai, Rachid Gouifrane, Rabia Qaisar, \\ Wissam El machtani El Idrissi, Ghizlane Chemsi, Mohamed Radid \\ Université Hassan II de Casablanca, Casablanca, Marocco \\ halimalajane@gmail.com
}

\begin{abstract}
The purpose of this research is to measure the motivation of nursing students, option: multi-skilled nurse $(n=58)$, following their participation in an e-learning activity in the form of formative quizzes. The pedagogical scenario was based on Keller's ARCS motivation model. Data were collected through the IMMS questionnaire adopted from the ARCS model. The results show that the students were motivated by the e-learning activity (mean score $=4.22 \pm, 51091$ ), and that the motivation variables studied correlated positively with the overall motivation score ( $\mathrm{p}$-value $<.001)$. Through this research, it was found that an instructional scenario based on the ARCS model had a positive impact on students' motivation for e-learning, thus encouraging allied health educators to design educational tools that can motivate nursing students.
\end{abstract}

Keywords - motivation, ARCS model, e- quiz, nursing education

\section{Introduction}

One of the fundamental activities that teachers use when planning courses is defining forms of evaluation, which includes formative assessment $[1,2]$. Through formative assessment, teachers review learners' understanding and obtain data on learning achieved for formative feedback $[3,4]$. In recent years, various studies have prompted changes in the way formative assessment is designed in the classroom to include digital assessment $[5,6,7]$. Moreover, technology-enabled formative assessment has demonstrated its significant pedagogical potential, particularly in terms of performance, commitment, and motivation to learn $[8,9,10,11]$.

Although the literature indicates that the use of digital technology generates levels of student motivation $[12,13,14]$, several questions remain about the nature of the implementation of distance learning materials and regarding how teachers can design tools to interest students in the learning process and maintain their motivation $[15,16]$. These topics are critical, as motivation remains one of the key factors that determine student learning outcomes [17]. 


\subsection{ARCS model of motivational design (Keller)}

There are many theories of motivation for learning, and each theory provides teachers with the basis for building student-accepted teaching tools [18]. One such theory is the ARCS model of John Keller's motivational design theories [19]. This theory presents four steps to promote student motivation in distance learning activities: attention, relevance, confidence and satisfaction.

The bases and principles of the ARCS model [20] can be summarized as follows:

- Attention: in this stage, it is necessary to arouse the learners' interest and stimulate their curiosity through a variety of methods when presenting the teaching material to encourage their active participation. This might include activities such as roleplaying, quizzes, and other methods. Visual stimuli and humor can also be used to capture attention during training.

- Relevance: in this stage, the aim is to design educational content that meets the students' learning needs. The teacher should show them how useful the material is and demonstrate how it will be used to develop their knowledge and skills.

- Confidence: in this stage, students must feel able to succeed in their training and understand their chances of success. Thus, learners must be aware of performance requirements and evaluation criteria.

- Satisfaction: in this stage, the learner is motivated to learn by appreciating their results. Learning should be made rewarding by providing feedback and reinforcement.

According to this model (figure 1), learners need a balance between all four principles (attention, relevance, confidence, and satisfaction) to promote and maintain their motivation to complete training or e-learning.

The objective of this work is, therefore, to study the motivational reactions of nursing students to a distance formative assessment activity based on the ARCS model, as part of the teaching of a surgical nursing course. More specifically, two research questions were asked:

- What are the motivational responses of nursing students to the online educational material?

- Which aspect(s) of the ARCS model most influence student motivation?

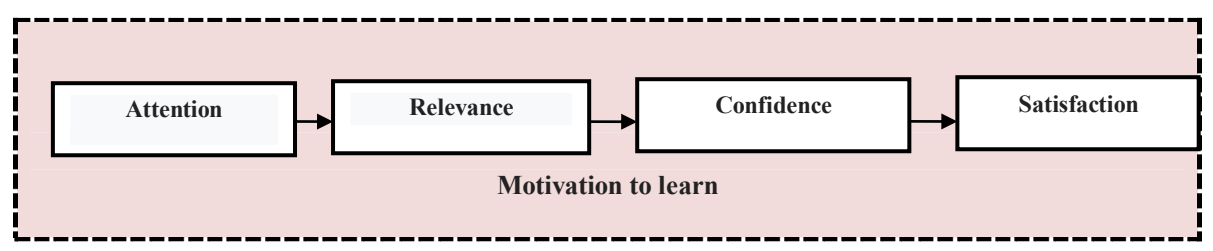

Fig. 1. ARCS Model of Motivational Design (Keller) 


\section{$2 \quad$ Material and method}

\subsection{The adopted pedagogical scenario}

The purpose of this study was to evaluate students' motivation after their participation in an e-learning activity. The learning activity used in this study was a series of formative quizzes built on a learning platform. The chosen setting was in a theoretical course entitled "Surgical Nursing." The design of the online quizzes met the principles of the ARCS model of motivation and respected a set of essential points presented in the table 1 .

Table 1. Design principles for online quizzes according to the ARCS model

\begin{tabular}{|ll|}
\hline $\begin{array}{c}\text { Dimensions of } \\
\text { motivation according } \\
\text { to IMMS }\end{array}$ & \\
\hline & - Formative evaluation in the form of quizzes \\
& - Student participation in the evaluation process \\
- Involvement and self-assessment & Autocorrection at the end of the quiz \\
Attention & - Choice of colors for the presentation \\
& - Quizzes illustrated with animations, images, and links \\
& - A variety of types of questions to attract attention \\
\hline Relittle mood ex: emoticon
\end{tabular}




\subsection{The participants}

The participants in this study were multi-skilled nursing students in their second year of initial training, enrolled in the professional license cycle $(n=58)$ at the Higher Institute of Nursing and Health Techniques of Casablanca. In 2020, these students participated in an e-learning activity.

\subsection{Measuring instrument}

To meet our research objective, we used Keller's IMMS questionnaire [21]. This questionnaire was developed as part of the ARCS model to measure learners' levels of motivation [19] regarding distance learning activities. The questionnaire consists of 36 questions with 5-point Likert scale items, and each group of questions is linked to a factor in the ARCS model. Here is the guide to the IMMS questionnaire (table 2).

Table 2. IMMS scoring guide

\begin{tabular}{|l|l|}
\hline Motivation element & Questions \\
\hline Attention (12 questions) & $\begin{array}{l}2,8,11,12 \text { (reverse), 15 (reverse), 17, 20, 22 (reverse), 24, 28, 29 (reverse), } \\
31 \text { (reverse) }\end{array}$ \\
\hline Confidence (9 questions) & 1.3, (reverse), 4,7, (reverse), 13,19(reverse), 25,34(reverse),35 \\
\hline Relevance (9 questions) & 6.9 .10 .16 .18 .23 .26 (reverse), 30,33, \\
\hline Satisfaction (6 questions) & $5,14,21,27,32,36$ \\
\hline
\end{tabular}

\subsection{Data analysis}

The data collected were analyzed using SPSS version 20 software. The internal consistency of the questionnaire was measured by calculating the Cronbach's $\alpha$. The results are presented as a mean and standard deviation to assess student motivation levels for each dimension of the questionnaire. A Pearson test was conducted to identify correlations between motivational factors and the overall motivation score. We also determined the correlation between the four factors.

An ANOVA test was carried out to discern whether there were differences in motivation levels between students based on their demographic characteristics.

\section{Results}

\subsection{Internal consistency of the IMMS questionnaire}

The internal consistency of the questionnaire was calculated by measuring the Cronbach's Alpha, found equal to 0.93 . Therefore, we determined that the questionnaire has a good internal consistency by comparing it with Keller's original questionnaire, which had a Cronbach's Alpha of 0.96. 
Table 3. The internal consistency of the questionnaire

\begin{tabular}{|l|l|l|l|l|}
\hline $\begin{array}{l}\text { Dimensions } \\
\text { Motivation }\end{array}$ & N of Items & $\begin{array}{c}\text { Reliability Estimate } \\
\text { (Cronbach) } \\
\text { Keller ( 1993) }\end{array}$ & $\begin{array}{c}\text { Cronbach's Alpha } \\
\text { in this stydie }\end{array}$ & $\begin{array}{c}\text { Cronbach's } \\
\text { Alpha Based } \\
\text { on } \\
\text { Standardized } \\
\text { Items }\end{array}$ \\
\hline Attention & $(12$ item) & 0.89 & 0.76 & 0.77 \\
\hline Relevance & $(9$ item) & 0.81 & 0.92 & 0.91 \\
\hline Confidence & $(09$ item $)$ & 0.90 & 0.63 & 0.64 \\
\hline Satisfaction & $(7$ item) & 0.92 & 0.92 & 0.92 \\
\hline Global score & $\mathbf{( 3 6}$ item) & $\mathbf{0 . 9 6}$ & $\mathbf{0 . 9 3}$ & $\mathbf{0 . 9 2}$ \\
\hline
\end{tabular}

\subsection{Motivation scores/ levels of motivation}

According to Table 4, the minimum level of motivation was 3.11 and the maximum level of motivation was 4.92 , with an average score of 4.22 , which is considered very positive. In addition, the data in Table 5 show that, among the 30 students who responded to the questionnaire, $21(70 \%)$ recorded a high level of motivation (between 4 and 5) as a result of their participation in the online learning activity, and $9(30 \%)$ recorded an average level of motivation (between 3 and 4). This suggests that the students were motivated by the numerical formative assessment.

Table 4. Motivation scores

\begin{tabular}{|l|r|r|r|r|r|}
\hline \multicolumn{7}{|c|}{ IMMS Motivation Scores (N=58) } \\
\hline & \multicolumn{1}{|c|}{ Attention } & \multicolumn{1}{|c|}{ Confidence } & \multicolumn{1}{c|}{ Relevance } & Satisfaction & $\begin{array}{c}\text { Motivation } \\
\text { (Total score= } 36 \\
\text { items })\end{array}$ \\
\hline N Valid & 58 & 58 & 58 & 58 & 58 \\
\hline Mean & 4,4833 & $\mathbf{3 , 9 3 3 3}$ & $\mathbf{4 , 0 7 7 8}$ & $\mathbf{4 , 3 6 6 7}$ & $\mathbf{4 , 2 2 5 0}$ \\
\hline Std. Deviation &, 41257 &, 52975 &, 81239 &, 78100 &, 51091 \\
\hline Minimum & 3,50 & 2,89 & 2,00 & 2,33 & $\mathbf{3 , 1 1}$ \\
\hline Maximum & 5,00 & 4,89 & 5,00 & 5,00 & $\mathbf{4 , 9 2}$ \\
\hline
\end{tabular}


Paper-A Scenario of the Formative E-assessment Based on the ARCS Model: What Is the Impact on...

Table 5. Classification of motivation levels according to the ARCS model

Motivation levels $(\mathbf{N}=\mathbf{5 8})$

\begin{tabular}{|l|l|l|l|}
\hline \multicolumn{1}{|c|}{ Score Ranges } & \multicolumn{1}{|c|}{ Motivation category } & Frequency N=30 & Percentage \\
\hline $\mathbf{1 4 4 - 1 8 0}$ & High motivation & $\mathrm{N}=40$ & $70 \%$ \\
\hline $\mathbf{1 0 9 - 1 4 3}$ & Average motivation & $\mathrm{N}=18$ & $30 \%$ \\
\hline $\mathbf{7 2 - 1 0 8}$ & Low motivation & $\mathrm{N}=00$ & $00 \%$ \\
\hline$<\mathbf{7 2}$ & Very low motivation & $\mathrm{N}=00$ & $00 \%$ \\
\hline
\end{tabular}

According to the ARC model of motivation, attention is the first element that students must have during a learning activity involving technology. In this research, the "Attention" variable had a average score of 4.48 with a minimum score of 4.20 (items 2 and 7) and a maximum score of 4.73 (item 8), showing that the Online Quizzes were positively engaging for the students and were catchy rather than boring.

The 2 nd element of the model is the relevance of the tool and the exercises proposed. The average score obtained was 3.93, with a minimum score of 3.8 (item 21) and a maximum score of 4.27 (item 14). This means that students believed the online quizzes to be relevant. In the Confidence variable, the average score obtained was 3.93 (minimum score $=3.8$ and a maximum score $=4.27$ ) showing that the quizzes were not difficult, which gave the students confidence that they could solve them.

In the last element of the model, satisfaction occupies an important place. In our study, the students were satisfied with the Online Quizzes and would like them to be included in other courses (average score $=4.36$; minimum score $=4.27$; maximum score $=4.53$ ). 
Table 6. Motivation levels by item/variable

\begin{tabular}{|c|c|c|c|}
\hline Items of IMMS & $\mathrm{N}$ & Mean & $\begin{array}{c}\text { Std. } \\
\text { Deviation }\end{array}$ \\
\hline \multicolumn{4}{|l|}{ Attention } \\
\hline $\begin{array}{l}\text { There was something very interesting in the wording of the quizzes } \\
\text { that caught my attention }\end{array}$ & 58 & 4,27 & 1,048 \\
\hline Online quizzes are really eye-catching & 58 & 4,20 & 1,031 \\
\hline The quality of the design of the quizzes caught my attention & 58 & 4,23 & ,935 \\
\hline The quizzes were very incomprehensible so I couldn't follow them & 58 & 4,73 &, 521 \\
\hline The quiz design was uninteresting and unattractive & 58 & 4,37 & ,964 \\
\hline The way the quizzes were written caught my attention & 58 & 4,53 & ,629 \\
\hline There were things in the quizzes that stimulated my curiosity & 58 & 4,20 & ,961 \\
\hline Sometimes I was bored with repetition & 58 & 4,73 & ,450 \\
\hline I've learned some surprising and unexpected things & 58 & 4,63 & ,490 \\
\hline $\begin{array}{l}\text { The variety of feedback, comments, and links helped me to get } \\
\text { interested in the quizzes }\end{array}$ & 58 & 4,57 & ,679 \\
\hline The quiz writing style was boring & 58 & 4,67 &, 802 \\
\hline There were several words in the quizzes that were really irritating & 58 & 4,67 &, 547 \\
\hline \multicolumn{4}{|l|}{ Confidence } \\
\hline $\begin{array}{l}\text { When I first looked at the online quizzes, I had the impression that it } \\
\text { would be easy for me }\end{array}$ & 58 & 3,83 & 1,053 \\
\hline The online quizzes were very difficult to solve that I thought & 58 & 4,27 & ,785 \\
\hline $\begin{array}{l}\text { After reading the introductory information, I knew what I was going } \\
\text { to learn from the quizzes }\end{array}$ & 58 & 3,97 & ,890 \\
\hline $\begin{array}{l}\text { It was difficult to choose or remember important points because there } \\
\text { was a lot of information in the exercises }\end{array}$ & 58 & 3,90 & 1,062 \\
\hline $\begin{array}{l}\text { When I started the quizzes, I was confident that I would be able to } \\
\text { solve them }\end{array}$ & 58 & 3,73 & 1,230 \\
\hline
\end{tabular}




\begin{tabular}{|c|c|c|c|}
\hline Relevance & & & \\
\hline $\begin{array}{l}\text { It was clear to me that the content of the quizzes was related to what I } \\
\text { already know }\end{array}$ & 30 & 3,83 & 1,053 \\
\hline $\begin{array}{l}\text { There were information, illustrations, and examples to show that these } \\
\text { quizzes can be important to students }\end{array}$ & 30 & 4,10 & 1,062 \\
\hline Solving the quizzes was really important to me & 30 & 4,07 & 1,081 \\
\hline The content of the quizzes was relevant to my learning interests & 30 & 3,97 & 1,159 \\
\hline $\begin{array}{l}\text { There were explanations and examples of how people use their knowledge } \\
\text { in these exercises }\end{array}$ & 30 & 3,80 & 1,031 \\
\hline $\begin{array}{l}\text { The design and writing style of the quizzes gave the impression that they } \\
\text { deserve to be solved }\end{array}$ & 30 & 4,10 & ,960 \\
\hline $\begin{array}{l}\text { The quizzes were not relevant to my needs because I already knew the } \\
\text { answers }\end{array}$ & 30 & 4,47 &, 730 \\
\hline $\begin{array}{l}\text { I could relate the content of the quizzes to what I saw in the course being } \\
\text { taught }\end{array}$ & 30 & 4,10 & 1,155 \\
\hline The content of the quizzes was useful for my learning & 30 & 4,27 & ,980 \\
\hline \multicolumn{4}{|l|}{ Satisfaction } \\
\hline $\begin{array}{l}\text { Completing the quizzes gave me satisfaction and a sense of } \\
\text { accomplishment }\end{array}$ & 30 & 4,27 & ,828 \\
\hline $\begin{array}{l}\text { I really liked the online quizzes and I wanted to do them in the other } \\
\text { courses }\end{array}$ & 30 & 4,53 &, 860 \\
\hline I had the pleasure of learning with the quizzes in the course & 30 & 4,43 &, 817 \\
\hline Feedback or comments after the exercises gave me rewards for my efforts & 30 & 4,17 & 1,053 \\
\hline It was good to pass these quizzes & 30 & 4,47 & ,973 \\
\hline It was a great pleasure to work on well-organized exercises & 30 & 4,33 & ,959 \\
\hline
\end{tabular}

\subsection{Correlation between motivation and ARCS variables}

To determine which of the four factors in the ARCS model (attention, confidence, relevance, and satisfaction) most influenced nursing students' motivation towards the 
online educational activity, we analyzed the data with a Pearson's correlation test, which revealed a correlation between the four factors and motivation ( $p$-value $<.001)$.

To assess whether there were differences in motivation levels among participants based on their characteristics (age, gender, baccalaureate track, and previous year's grade), an ANOVA test was performed. The results of this test did not signify a significant difference between all factors.

In addition to the data presented, an examination of the correlation between the four motivation variables indicated that they correlate with each other quite significantly ( $p$ value $<.001)$.

Table 7. Correlation between motivation and ARCS variables

\begin{tabular}{|c|c|c|c|}
\hline \multicolumn{3}{|c|}{ Correlation Between Motivation and ARCS Variables } & \multirow{2}{*}{$\begin{array}{r}\text { Motivation } \\
, 735^{* *}\end{array}$} \\
\hline \multirow[t]{12}{*}{ Pearson 's Correlation } & \multirow[t]{3}{*}{ Attention } & Correlation Coefficient & \\
\hline & & Sig. (2-tailed) &, 000 \\
\hline & & $\mathrm{N}$ & 58 \\
\hline & \multirow[t]{3}{*}{ Confidance } & Correlation Coefficient & $842^{* *}$ \\
\hline & & Sig. (2-tailed) &, 000 \\
\hline & & $\mathrm{N}$ & 58 \\
\hline & \multirow[t]{3}{*}{ Relevance } & Correlation Coefficient & $915^{* *}$ \\
\hline & & Sig. (2-tailed) &, 000 \\
\hline & & $\mathrm{N}$ & 58 \\
\hline & \multirow[t]{3}{*}{ Satisfaction } & Correlation Coefficient &, $739^{* *}$ \\
\hline & & Sig. (2-tailed) &, 000 \\
\hline & & $\mathrm{N}$ & 58 \\
\hline
\end{tabular}

*. Correlation is significant at the 0.05 level (2-tailed).

**. Correlation is significant at the 0.01 level (2-tailed).

$* * \mathrm{p}$ value $<.001$ 
Table 8. Correlation within ARCS conditions

\begin{tabular}{|c|c|c|c|c|c|c|}
\hline & & & Attention & Confidance & Relevance & Satisfaction \\
\hline \multirow{13}{*}{ Pearson's rho } & \multirow{3}{*}{ Attention } & Correlation Coefficient & 1,000 & ,429* &, $588^{* * *}$ & $368^{*}$ \\
\hline & & Sig. (2-tailed) & & 018 & ,001 &, 045 \\
\hline & & $\mathrm{N}$ & 58 & 58 & 58 & 58 \\
\hline & \multirow{3}{*}{ Confidance } & Correlation Coefficient &, $429^{*}$ & 1,000 &, $762^{* *}$ &, $580^{* *}$ \\
\hline & & Sig. (2-tailed) & ,018 & & ,000 & ,001 \\
\hline & & $\mathrm{N}$ & 58 & 58 & 58 & 58 \\
\hline & \multirow{3}{*}{ Relevance } & Correlation Coefficient &, $588^{* *}$ &, $762^{* *}$ & 1,000 &, $723^{* *}$ \\
\hline & & Sig. (2-tailed) & ,001 &, 000 & &, 000 \\
\hline & & $\mathrm{N}$ & 58 & 58 & 58 & 58 \\
\hline & \multirow{4}{*}{ Satisfaction } & Correlation Coefficient & $368^{*}$ &, $580^{* *}$ &, $723^{* *}$ & 1,000 \\
\hline & & Sig. (2-tailed) & , 045 &, 001 &, 000 & \\
\hline & & & & & & \\
\hline & & $\mathrm{N}$ & 58 & 58 & 58 & 58 \\
\hline
\end{tabular}

*. Correlation is significant at the 0.05 level (2-tailed).

**. Correlation is significant at the 0.01 level (2-tailed).

\section{Discussion}

Measuring motivation is essential to evaluate the effectiveness of an instructional scenario. The goal of this research was to study nursing students' motivation towards an online learning activity (formative quizzes) based on the ARCS model of motivation. According to the model, the scores obtained through the distributed questionnaire demonstrate positive motivation following the students' participation in a distance learning activity. The average motivation score was 4.22 and $70 \%$ of the participants recorded high motivation (between 4 and 5). All the variables studied correlated positively with the total motivation score.

Our results corroborate those of other similar studies; particularly research conducted using the ARCS model of motivation. For example, David et al. (2009) [22] reported that pedagogical changes based on the ARCS model can enhance motivation and improve learning and that trainers can apply the model effectively. Similarly, another study conducted by Huang (2016) [23] to measure participant motivation in the mass implementation of open online courses (MOOCs) using the IMMS questionnaire found that the motivation level of most participants was positive and that they were satisfied with the pedagogical materials provided in the MOOCs. However, learners also anticipated improvements in some areas.

More recently, Kimberly (2019) [24] concluded that learning and assessment strategies based on the ARCS model can be effectively used to improve and maintain participant motivation in a pharmacy elective. 
In summary, other studies in the literature have highlighted the value of applying the ARCS model based on the four dimensions of motivation (attention, confidence, relevance, and satisfaction) in the design and development of educational tools. This provides a method for teachers, particularly in the nursing sciences, to adopt effective teaching and learning strategies regarding engagement and motivation.

\section{Conclusion}

Based on the data from this study, although conducted with a small sample $(\mathrm{N}=58)$, a pedagogical scenario based on the ARCS model can stimulate students' motivation to follow an e-learning activity.

In fact, the overall results showed a satisfactory motivation score of $n=4.22$, and the students enjoyed this learning activity enough to want to repeat it in other courses. This finding provides nursing educators with avenues for developing educational materials that motivate learning and breaks with traditional models of formative evaluation that have historically been practiced in paper-and-pencil format.

\section{Ethical considerations}

Prior to the administration of this study, ethical aspects were taken into consideration. These include the agreement obtained from the Moroccan Ministry of Health to carry out this study, which is part of the preparation of a nursing sciences thesis. It should also be noted that participation in this study was voluntary, and the informed consent of students was obtained after an explanation of the purpose of the study.

\section{$7 \quad$ References}

[1] Allal, L., \& Mottier Lopez, L. (2005). Formative assessment of learning: A review of publications in French. In J. Looney (Ed.), Formative assessment: Improving learning in secondary classrooms, ISBN-92-64-00739-3 (C) OECD.

[2] Wiliam D, Thompson M. (2008). Integrating assessment with instruction: What will it take to make it work? In: Future of assessment: Shaping teaching and learning. p. 53-82. https://doi.org/10.4324/9781315086545-3

[3] Chand Tuttle HG. (2009). Formative Assessment: Responding to Your Students. Eye On Education. 159 p. ISBN 978-1-59667-096-9.

[4] Black P, William D. (1998). Assessment and Classroom Learning. Assessment in Education: Principles, Policy \& Practice ;5(1):7-74. https://doi.org/10.1080/0969595980050102

[5] Pachler N, Daly C, Mor Y, Mellar H. (2010). Formative e-assessment: Practitioner cases. Comput Educ ;54(3):715-21. https://doi.org/10.1016/j.compedu.2009.09.032

[6] Ali, F. and George, A. (2015). Impact of a Formative e-Assessment on Learning Outcomes: A Pilot Study on a Social and Behavioural Sciences Course, College of Health Sciences, University of Bahrain, Fifth International Conference on e-Learning (econf), Manama, pp. 408-412, https://doi.org/10.1109/ECONF.2015.38 
Paper-A Scenario of the Formative E-assessment Based on the ARCS Model: What Is the Impact on...

[7] Bahati B, Fors U, Hansen P, Nouri J, Mukama E.(2019). Measuring Learner Satisfaction with Formative e-Assessment Strategies. Int J Emerg Technol Learn IJET.;14(07):61. https://doi.org/10.3991/ijet.v14i07.9120

[8] Sadia, R. \& Awang R., Dayang \& Salleh, Rohani \& Mushtaq, A. \& Riaz, S. (2010). Study to Investigate Learning Motivation Factors within Formal and Informal Learning Environments and their influence upon Web-Based Learning. International Journal of Emerging Technologies in Learning. 5. https://doi.org/10.3991/ijet.v5i4.1338

[9] Navarro, Óscar \& Sánchez-Verdejo Pérez, Francisco Javier \& Anguita, Juana \& González Olivares, Ángel. (2020). Motivation of University Students Towards the Use of Information and Communication Technologies and Their Relation to Learning Styles. International Journal of Emerging Technologies in Learning (iJET). 15. 202. https://doi.org/10.3991/ijet. $\underline{\mathrm{v} 15 \mathrm{i} 15.14347}$

[10] Chen H-Y, Chuang C-H. (2012). The learning effectiveness of nursing students using online testing as an assistant tool: A cluster randomized controlled trial. Nurse Educ Today.;32(3):208-13. https://doi.org/10.1016/j.nedt.2011.03.004

[11] Webb L, Clough J, O'Reilly D, Wilmott D, Witham G. (2017). The utility and impact of information communication technology (ICT) for pre-registration nurse education: A narrative synthesis systematic review. Nurse Educ Today. janv 2017; 48:160-71. https://doi.org/ 10.1016/j.nedt.2016.10.007

[12] River, J., Currie, J., Crawford, T., Betihavas, V., Randall, S. (2016). A systematic review examining the effectiveness of blending technology with team-based learning. Nurse Educ. Today 45:185-192. https://doi.org/10.1016/j.nedt.2016.08.012

[13] Yin, Yue, Shavelson, Richard J., Ayala, Carlos C., Ruiz-Primo, Maria Araceli, Brandon 1, Paul R., Furtak, Erin Marie,Tomita, Miki K. and Young, Donald B.(2008). On the Impact of Formative Assessment on Student Motivation, Achievement, and Conceptual Change',Applied Measurement in Education, 21:4, 335-359. https://doi.org/10.1080/089 $\underline{57340802347845}$

[14] Chemsi, G. \& Sadiq, M. \& Radid, M. \& Talbi, M. (2020). Study of the Self-Determined Motivation among Students in the Context of Online Pedagogical Activities. International Journal of Emerging Technologies in Learning (iJET). 15. 17. https://doi.org/10.3991/ ijet.v15i05.11392

[15] Tomasik MJ, Berger S, Moser U. (2018). On the Development of a Computer-Based Tool for Formative Student Assessment: Epistemological, Methodological, and Practical Issues. Front Psychol. 2018;9:2245. Published 2018 Nov 20. https://doi.org/10.3389/fpsyg. 2018.02245

[16] Elmahdi DI. (2018). Using Technology for Formative Assessment to Improve Students' Learning. Turk Online J Educ Technol. 2018;17(2):8.

[17] Jamil MM, Ningrum E, Yani A. (2019). Level of Learning Motivation Student Based on ARCS Model on Geographic Subject. IOP Conf Ser Earth Environ Sci. 28 juin 2019;286:012010. https://doi.org/10.1088/1755-1315/286/1/012010

[18] Valarmathie Gopalan, Juliana Aida Abu Bakar, Abdul Nasir Zulkifli (2020). A review of motivation theories, models and instruments in learning environment. Journal of Critical Reviews, Vol 7, Issue 6, 2020, http://dx.doi.org/10.31838/jcr.07.06.100

[19] Keller, J. M. (1987). Development and use of the ARCS model of instructional design, "Journal of instructional development, vol. 10, no. 3, pp. 2-10. https://doi.org/10.1007/ BF02905780

[20] Keller John M. (2016). Motivation, Learning, and Technology: Applying the ARCS-V Motivation Model. Participatory Educational Research (PER). Vol. 3(2), pp. 1-13, Available online at https://doi.org/10.17275/per.16.06.3.2 ISSN: 2148-6123. 
[21] Keller, J.M. (2010). Motivational Design for Learning and Performance: The ARCS Model Approach. New York, NY: Springer. https://doi.org/10.1007/978-1-4419-1250-3 2

[22] Cook DA, Beckman TJ, Thomas KG, Thompson WG. (2009). Measuring Motivational Characteristics of Courses: Applying Keller's Instructional Materials Motivation Survey to a Web-Based Course: Acad Med; 84(11):1505-9. https://doi.org/10.1097/ACM.0b013e3 $\underline{181 \mathrm{baf} 56 \mathrm{~d}}$

[23] Huang, B, Hew, KF. (2016). Measuring Learners' Motivation Level in Massive Open Online Courses. The Division of Information and Technology Studies, Faculty of Education at the University of Hong Kong, Pokfulam Road, Hong Kong. Int J Inf Educ Technol. 2016;6(10):759-64. https://doi.org/10.7763/IJIET.2016.V6.788

[24] Craig, K. (2018). Motivation in Instructional Design (Dissertation, Université Concordia, St. Paul). Récupéré de https://digitalcommons.csp.edu/edd/2

\section{Authors}

Halima Lajane is a Ph.D in Educational Technology. She is head of the organization of hospital education at the Ibn Rochd university center, Morocco. She is a member of Association for the Development of Evaluation Methodologies In Education (ADMEE)-Section Morocco. She is a member of Laboratory of Physical Chemistry of Materials (LCPM) at Ben M'Sik Faculty of Sciences, Hassan II University of Casablanca, Morocco.

Arai Mounir is a $\mathrm{PhD}$ in Hospitality and Infectious Risk Prevention-Faculty of Medicine and Pharmacy-Casablanca Morrocco.he is a hygienist nurse, member of the Moroccan society of hygiene Hosiptaliére.

Rachid Gouifrane is a Ph.D in Educational Technology. He is a Nurse Teacher and the head of continuing education office at Ibn Rochd hospital of Casablanca, Morocco. $\mathrm{He}$ is a member of Association for the Development of Evaluation Methodologies In Education (ADMEE)-Section Morocco. He is a member of Laboratory of Physical Chemistry of Materials at Ben M'Sik Faculty of Sciences (LCPM), Hassan II University of Casablanca, Morocco.

Rabia Qaisar is a Ph.Dc in Educational Technology. She is a Nurse Teacher at Higher Institute of Nursing and Health Techniques of Casablanca. She is a member of the Multidisciplinary Laboratory in Sciences and Information Communication and Education Technology (LAPSTICE) at Ben M'Sik Faculty of Sciences, Hassan II University of Casablanca, Morocco.She is a member of Association for the Development of Evaluation Methodologies In Education (ADMEE)-Section Morocco.

Wissam El machtani El Idrissi is a Ph.Dc in Educational Technology. She is a Nurse Teacher at Higher Institute of Nursing and Health Techniques of Casablanca. She is a member of Association for the Development of Evaluation Methodologies In Education (ADMEE)-Section Morocco. She is a member of Laboratory of Physical Chemistry of Materials (LCPM) at Ben M'Sik Faculty of Sciences, Hassan II University of Casablanca, Morocco.

Ghizlane Chemsi: is a PhD in Educational Technology. She is a Professor at Faculty of Sciences Ben M'Sik, University Hassan II of Casablanca, Morocco, B.P 7955 Sidi 
Othmane. She operates in several fields of educational sciences: educational technologies and assessment, engineering of assessment. She is a Member of the Observatory of Research in Didactics and University Pedagogy (ORDIPU), Member of Association for the Development of Evaluation Methodologies in Education (ADMEE) - section Morocco and the Multidisciplinary Laboratory in Sciences and Information Communication and EducationTechnology (LAPSTICE).

Mohamed Radid is a PhD in Physical Chemistry. He is currently the Vice Dean of the Faculty of Sciences Ben M'Sik at Hassan II University, B.P 7955 Sidi Othmane, and Casablanca, Morocco since 2014. He is a Member of the Observatory of Research in Didactics and University Pedagogy (ORDIPU) and Member Board of Directors of Association for the Development of Evaluation Methodologies in Education (ADMEE) - Europe. He is an Expert in the fields of teaching and research on educational and technologies assessment, engineering of assessment, Chemistry Didactics, University Pedagogy.

Article submitted 2021-05-20. Resubmitted 2021-10-20. Final acceptance 2021-10-20. Final version published as submitted by the authors. 